\title{
FRENCH PROTESTANTISM AND ITS AMBIVALENT ATTITUDE TOWARD CULTURE'
}

\author{
Paul Wells \\ North West University (RSA) \\ Correspondence: pauliowells@gmail.com
}

\begin{abstract}
Protestantism in France has an ambiguous attitude to the surrounding culture, because of its position as a small minority. The other forces present are Roman Catholic authoritarianism and the liberal free-thinking of Enlightenment humanism, represented by the likes of Voltaire and Rousseau. The paradox is that since the Revolution in 1789, which was antiroyal and anti-religious, when Protestantism has sided with the majority Roman Church it has undermined its Reformed identity, and when it has sided with libertarian free-thinking it has undermined its Christian identity. This remains a feature of French Protestantism until the present day. As a result of this tension, the thought of one of France's greatest thinkers, John Calvin, became virtually unknown, not only in French culture and society as a whole, but also within French Protestantism itself.
\end{abstract}

KEYWORDS: Protestant, Reformed, French, Catholic

ABSTRAK: Protestantisme di Prancis memiliki sikap ambigu terhadap budaya disekitarnya, karena posisinya sebagai minoritas kecil. Kekuatan lain yang hadir adalah otoritarianisme Katolik Roma dan pemikiran bebas liberal humanisme Pencerahan, diwakili oleh orang-orang seperti Voltaire dan Rousseau. Paradoksnya adalah bahwa sejak Revolusi tahun 1789, yang anti-kerajaan dan anti-agama, ketika Protestan memihak mayoritas Gereja Roma, ia telah merusak identitas Reformednya, dan ketika telah menyamping dengan pemikiran bebas libertarian, ia telah merusak identitas Kristennya. Ini tetap menjadi fitur Protestanisme Prancis hingga saat ini. Sebagai hasil dari ketegangan ini, pemikiran salah satu pemikir terbesar Prancis, John Calvin, menjadi hampir tidak dikenal, tidak hanya dalam budaya dan masyarakat Prancis secara keseluruhan, tetapi juga di dalam Protestanisme Prancis itu sendiri. 
KATA KUNCI: Protestan, Reformed, Prancis, Katolik

Many people visiting France expect to find in Calvin's homeland some traces of Calvin's thought. However, they find none at all and this surprises them. Why should this be so, when Calvin is so famous throughout the world? Even more, when they know the culture a little, they will find that there is no faith and life view as one expects where the Reformed faith has had an influence. Rather the relationship between faith and culture in French Protestantism is different from in Protestantism elsewhere in Europe or in the world for that matter.

There are several reasons for this; at least three factors affected the particular development of Protestantism in France:

Calvin's theology has been almost entirely forgotten not only by French society, though the influence first of persecution and then the French Revolution in 1789, but also in French Protestant churches of all kinds. In particular Calvin's teaching on revelation, grace and common grace is unknown.

The revivals of the 19th century pushed Protestantism either towards pietism or in reaction towards a social, humanistic gospel. Thus, evangelicals and liberals polarized against each other on right and left.

As a minority in society Protestantism had to define its identity with regard to the two majority groups present before and after the French Revolution. This is of prime importance and we will concentrate on this complex relationship in what follows.

In France Protestantism in its historical development found itself between a rock and a hard place. Firstly, there was the rejection of the Reformation and the persecution that followed during the wars of religion and after when Protestantism was outlawed by the monarchy and the Roman Catholic Church. Secondly came the rise of the secular mentality (called laïcité in French). It has always been difficult for Protestantism to find a place between these two realities. ${ }^{1}$ It has always been a struggle to establish an identity between the Church and Republican values, strongly influenced by free-thinking and atheism. ${ }^{2}$ From its middle ground somewhere between the two main French ideologies, Protestantism has tried to

1 Cf. Paul Wells, "Calvin and France: A Paradoxical Legacy," in H. van den Belt, ed., Restoration through Redemption: John Calvin Revisited (Leiden: Brill, 2013); Jean Baubérot, Le Protestantisme doit-il mourir? (Paris: Seuil, 1988), Annexe II.

2 Baubérot, ibid., $223 \mathrm{ff}$. 
develop affinities with both camps. ${ }^{3}$

In this situation it has been more or less impossible to develop a theology of faith and life or to manifest an independent cultural identity. Instead of developing a faith and life mentality, French Protestantism has chosen between the one of the other, favouring either leading people to faith or getting involved in social work, often in a political left way.

In the 19th century Protestantism found its allies in forward-looking "progressive" political and social movements. Its social involvement, through its many charitable institutions, enabled it to exert an influence that went far beyond its numerical importance. In the 20th century, however, when it joined forces with majority Catholic religion in the Ecumenical movement, it fell back into the position of being the younger sibling in the shadow of the bigger brother.

The first outcome was that Protestant Churches fell under the ideological influence of secular humanism, and their message became scarcely different from ideas prevailing in society at large. This was no doubt accentuated by the institutional weakness that characterized these churches. ${ }^{4} \mathrm{Closer}$ ties between the church and secular progressive social movements watered down the Christian character of Protestantism. ${ }^{5}$ This happened to a lesser degree and much later in Roman Catholicism, the majority church, very strong in numbers, where as Protestants were very few. Even today there are five times more Muslims than Protestants in France. This development can be seen particularly in some varieties of Protestant theological liberalism. Unlike Catholicism, Protestantism was credible as a religion because it held certain things in common with the Revolution and its progressive core values, liberty, equality, and fraternity. ${ }^{6}$

The more the Roman Catholic Church was hostile to Protestantism, the more it pushed it towards a closer alliance with others who were basically hostile to the Christian faith, or who were interested only the moral aspects of Christianity. ${ }^{7}$ At the same time, Protestantism had a positive social role because of its stand on tolerance and freedom. Its teaching on freedom of conscience seemed to provide a counterpoint to the problem of Church authoritarianism. Protestants had stood up to abuse for such a long time they seemed to provide an exemplary model for social resistance against

3 Baubérot, ibid., 233. On the "deux France," cf. Jean Baubérot, La morale laïque contre l'ordre moral (Paris: Seuil, 1997).

4 Jean-Paul Willaime, La précarité protestante (Genève: Labor \& Fides, 1992$), 11$.

5 Steve Bruce, A House Divided. Protestantism, Schism and Secularisation (London and New York: Routledge, 1990).

6 Eugène Réveillaud (1851-1935) dans son livre La question religieuse et sa solution protestante (1878).

7 Baubérot, Le Protestantisme, op. cit., 46. 
abuses and a stimulus for change. ${ }^{8}$ It found its allies against forces hostile to progress ${ }^{9}$ in a « secular pact » (le pacte laïque). ${ }^{10}$ Paradoxically, Protestantism in the 19th century became a rationalistic form of Christianity and revolutionary values took on a spiritual dimension. ${ }^{11}$ Victor Hugo's Les Misérables is a good example of this as can be seen even in the recent movie. From this perspective specifically Protestant cultural projects became superfluous. Its main function was to fight for its freedom.

Consequently, in the 20th century, Protestantism was more influenced by secularisation than Catholicism, at least visibly, to a large extent because of the strength in numbers of the majority Roman Catholic Church. ${ }^{12}$ Three factors have contributed to deterring Protestants from developing their own cultural programmes:

Firstly, ecumenism was the first factor. From the 1930's on, Barthian theology, more in France than in the Anglo-Saxon countries, gave Protestant churches a credibility as partners for dialogue with Catholicism, ${ }^{13}$ allowing them to come out of religious isolation. In a society in which religion had become a private matter ecumenism became a valid function for religion. ${ }^{14}$ In this way practising Protestants showed openness to change. Ecumenism was a kind of spiritual rearmament for Protestants and became a proof of Christian authenticity. ${ }^{15}$

Ecumenism was generally a great deal more important for Protestantism than for Catholicism in France because of sheer numbers, and involved many more risks for Protestants. ${ }^{16}$ It became more acceptable among bona fide Protestants to call oneself Christian before admitting to being Protestant. Something fundamentally true on the level of faith was subversive in so far as the Protestant Church as an institution was concerned. Jean Baubérot, a leading French sociologist goes so far as to say that this attitude has endangered the very existence of Protestantism in France. ${ }^{17}$ It even amounted to a kind of sociological suicide. ${ }^{18}$ After 1968, in particular, a large number of members haemorrhaged from Protestantism because of inter-faith marriages

\footnotetext{
Baubérot, ibid., 49.

Baubérot, Le retour des Huguenots (Paris/Genève: Cerf/Labor \& Fides, 1985), 77-80.

10 Baubérot, ibid., chap. 1, and 301f.

11 Cf. Philippe Joutard, (ed.), Historiographie de la Réforme (Neuchâtel: Delachaux et Niestlé, 1977), 171-181.

12 Baubérot, Le Protestantisme, op. cit., 71ff.

13 Willaime, La précarité, op. cit., 41ff, 166-168.

14 Baubérot, Le Protestantisme, op.cit., 91.

15 Willaime, La précarité, op. cit., 166.

16 We refer to ecumenism with Catholics. Protestants in France have generally been luke-warm with regard to the World Council of Churches, particularly since 1990.

17 Baubérot, Le Protestantisme, op.cit., 97.

18 As says Willaime, «Risques et atouts de la précarité protestante», 34.
} 
called "mixed marriages".

One of the results of ecumenism was that it came to seem sectarian to have projects that were strictly and exclusively run by Protestants, either Evangelical or Reformed, even when it came to evangelism. The French Bible Society showed the way by getting Catholics to cooperate in Bible translation and by pioneering the Ecumenical Translation of the Bible (TOB).

The second aspect concerned the «scandal » of the Reformation. For a long time Catholic historiography interpreted the Reformation as being the first step of a headlong fall into free-thinking Enlightenment humanism. The Roman Church found a strange ally in its interpretation of history in liberal Protestantism. The liberal Paris theologian of the 19th century Auguste Sabatier, argued that the Reformation was a step towards total freedom of conscience and a forerunner of modern definitions of tolerance. ${ }^{19}$ This suited the Roman Catholic view of Protestantism very well!

As a result, for a large number of Protestants, the Reformation became a rather embarrassing inheritance, even to the extent that in the collective Protestant mind, in the context of openness and ecumenical dialogue, it seemed to have been a great mistake, a parenthesis, a page of history to be turned and forgotten.

In the third place, adaptability has always been the strong point of Protestantism, but this very strength has borne in itself the seeds of self-destruction. In a modern or hypermodern society strong convictions about religion are not appreciated, and have gone out of fashion. People are quite happy to live without fixed ideas about meaning or ultimate truth. ${ }^{20}$ The climate of extreme relativism of secular French culture has served to heighten the classical tension between liberalism and orthodoxy within Protestantism. Theological pluralism was welcomed as a way to historical truce by the various parties present in the main line churches. This kind of pluralism favored off-the-peg theology and opened a kind of « vacuum period » (ère du vide) on the confessional level. Steve Bruce stated that non-believers are rarely converted to theological liberalism; it would be legitimate to ask whether pluralism is not similar in this respect. ${ }^{21}$ In fact in Protestant churches religious pluralism became the only point at which the churches found their unity as they no longer agreed on the main truths of Christianity like the Trinity or the sacrificial death of Christ. Someone even said that it had become an addition to the Apostles' Creed!

19 Baubérot, op.cit., 97-102

20 Gilles Lipovetsky, L'ère du vide. Essais sur l'individualisme contemporain (Paris: Gallimard, 1983), 44.

21 Bruce, A House Divided. 109, chaps. 5, 6. 
Pluralism has so weakened the living strength of Protestant convictions that a relativistic mentality has become prevalent. Protestants are disinclined to set up ventures of their own but have rather chosen to join forces with the progressive elements in society. For example, the case of Protestant women active in the development of the family planning movement in the 1960's who later became more feminist and pioneered abortion too.

These factors do not in and of themselves explain why mainline Protestantism has declined, but they illustrate in a significant way the cultural inertia of historical Protestantism. According to Jean Baubérot, it is no accident if the brand of Protestantism in decline today is that of the main line churches that have joined forces with secularism and ecumenism ${ }^{22}$ whereas new evangelicalism is growing in an encouraging way and gaining confidence.

We can take little comfort from saying that success can be found in the «Protestantisation » of French society, since institutional Protestantism today has lost its savour, and has little appeal for the secular people it may have influenced the most as a religion of tolerance. 